\title{
THE PRACTICE OF DOWER AND DOWRY IN MUSLIM MARRIAGE IN BANGLADESH: A LEGAL ANALYSIS
}

\author{
Nahid Ferdousi ${ }^{1}$
}

\begin{abstract}
Dower and dowry have become two common terms of Muslim marriage in Bangladesh. Dower is an exclusive right of Muslim wife to receive a part of the husband's income at any time after marriage. Though it enhances the status and security of the Muslim, there is a situation where a wife does not receive dower from husband due to various socio-legal reasons. Moreover, there is a situation where a woman loses her legal rights of dower while she is entitled under both the Shariah and statutory laws. Then, there is an occurrence where a woman and her family become the victims of dowry practice by the husband even though it is unIslamic. Nevertheless, there are some challenges to recover the dower but a dowry victim does not receive justice from laws and tradition. The article analyses the challenges of woman's right for dower practice under the Shariah and Statutory laws and the impact of the traditional practice of dowry offer some suggestions for improving the family justice in Bangladesh.
\end{abstract}

Keywords: dower, dowry, practice, impact, Shariah, statutory law

1 Professor of Law, School of Social Sciences Humanities and Languages, Bangladesh Open University, ferdousi329@gmail.com 


\section{INTRODUCTION}

The most important event in a woman's life is the marriage which is surrounded by various financial transactions including dower and dowry in Bangladesh. In Muslim Marriages, the dower is considered as an essential part under the Shariah. It is a woman's right to receive marital property which the wife is entitled to receive from her husband in consequence of their marriage and she can claim it during and after the marriage. Therefore, it is designated to protect the woman accordingly. ${ }^{2}$ Thus, it is an important subject matter for the Muslim society and considered as an obligation imposed by the Muslim family laws on the husband. Therefore, both under Shariah and Muslim family laws, dower rights for women are mandatory in any Muslim marriage in Bangladesh. ${ }^{3}$

In reality, women often are deprived of her dower right because it is controlled by husband and social custom. Indeed, a smaller amount for dower has been adjusted by the husband's family and the customary practice to waive dower in the wedding night and it is existing in the country. Sometimes, the groom's party have a lack of responsibility towards the items related to dower at the time of marriage. Similarly, dower is being curtailed by turning talaq case into the payment of dower or they even want to use the traditional concept of usool (paid) by jewellery or o khula where the woman has to sacrifice her right of dower in exchange for a divorce etc. ${ }^{4}$

There is a wrongful belief revolving most of the women regarding dower that the right to demand for dower only arises at the time of divorce. Apart from these, regarding cases of unregistered marriage and also when there is a non - specification of the mode of payment of dower in the Kabinnama, women cannot claim dower at the right time. By this way, the cases of dower are influenced by social practice and the question of payment arises only at the time of divorce. Because of this, women often deprived of their right and her dower money. ${ }^{5}$

2 David Pearl \& Werner Manski, Muslim Family Law (Lahore, Pakistan: Brite Books, 1998), 179.

3 Aqil Ahmed, Mohammedan Law, $21^{\text {st }}$ ed. (Allahabad: Central Law Agency, 2004), 148.

4 Taslima Monsoor, From Patriarchy to Gender Equity: Family Law and Its Impact on Women in Bangladesh (Dhaka: The University Press Limited, 1999), 222.

5 Farah Deeba Chowdhury, 'Dowry, Women, and Law in Bangladesh', International Journal of Law, Policy and the Family, vol. 24/2 (2010): 198-221. 
However, another marital practice in the country is the husband's demand for dowry from the wife's family which is not supported by Shariah and Muslim family laws. ${ }^{6}$ Most of the wife's family did not agree willingly with this demand for dowry from the husband's family sides. If the wife or her family sides want to give money or property to the newlywed couple; this will be regarded as gifts of marriage and not assumed as dowry. In reality wife's family are facing pressure regarding the demand for dowry from husband's and his family. The practice of payment of dowry has long been prohibited by the Dowry Prohibition Act $^{7}$ even though it still exists in the country. In the social context, dowry looked upon as financial security, gift and capital money for the new couple so that a husband could invest some amount of the dowry for business or facilitate maintenance for their new family. ${ }^{8}$ Once dowry being paid according to the demand of the husband practice of demanding dowry becomes a regular. ${ }^{9}$ Sometimes, dowry could be seen as going against the nature of mankind and often exceeds the dower's expected amount. Also, dowry encourages polygamy, frequent marriages, divorce, etc. which could bring women and their family suffer a lot because of the dowry system in the country. ${ }^{10}$

In recent times, the dowry system has affected the Muslim society that it has spread from the upper class down to the low-income class. ${ }^{11}$ The original antidowry law deals with dowry was seen as not comprehensive in this regards. ${ }^{12}$ Furthermore, in 2018, the government has enacted a new anti-dowry law to eliminate dowry and related violence. The objective of the study is to find out the dower and dowry practice under the Shariah and statutory laws along with social tradition in Bangladesh.

$6 \quad$ Taslima Monsoor, Management of Gender Relations: Violence against Women and Criminal Justice System in Bangladesh (Dhaka: British Council, 2008), 15.

7 The Dowry Prohibition Act 1980 (amended in 1984, 1986) and finally the Act 1980 has been repealed by the Dowry Prohibition Act 2018.

8 Nusrat Ameen, 'Dowry in Bangladesh: How Many More Deaths to Its End?' Journal of Faculty of Law, The Dhaka University Studies, vol. 8/1 (1997): 128.

9 Farah Deeba Chowdhury, 'Dowry, Women, and Law in Bangladesh', 198-221.

10 Report of Human Rights Organization 'Odhikar', Annual Human Rights Report on Bangladesh, 2015.

11 David Pearl \& Werner Manski, Muslim Family Law, 179.

12 The Dowry Prohibition Act 1980, section 4. 


\section{MATERIALS AND METHODS}

This study is written primarily by taking the primary and secondary sources such as existing laws, acts, books, journal and other published works as well as NGO's reports, features of national daily newspapers. Additionally, available published research reports and articles are taken into consideration while developing arguments and analysis of different dimension of the social practice of dower and dowry in Bangladeshi society.

\section{DOWER UNDER THE SHARIAH AND THE MUSLIM FAMILY LAWS}

Dower is a personal right of a woman that is entitled to her in marriage under Islam as well as enacted by Muslim family laws in Bangladesh. The concept of dower ( $m a h r)$ has its origin in Islam and it also offers many other rights and protection of wife in a marriage. The Holy al-Qur'ān says:

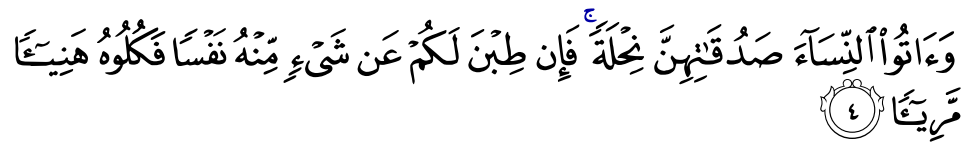

"And give to the women (whom you marry) their mahr (bridal gifts) with a good heart, but if they give up willingly to you anything of it, then take it in satisfaction and ease."

(Surah al-Nisā', 4: 4)

This provision makes the command for dower (mahr) as crystal clear. This means that the dower belongs to women exclusively and it is considered as gifts to be paid directly to them. Some more pieces of evidence mentioned in the Holy al-Qur'ān are:

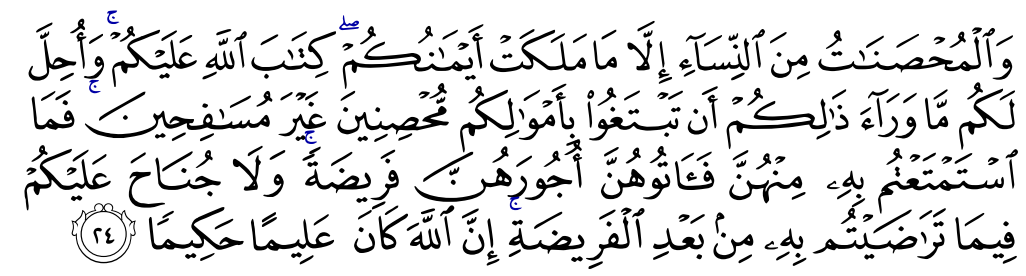

"And all married women except those whom your right hands possess (this is) Allah's ordinance to you, and lawful for you are (all women) besides those, provided that you seek (them) with your property, taking (them) in marriage not committing fornication. Then as to those whom you profit by, give them their dowries as 
appointed; and there is no blame on you about what you mutually agree after what is appointed; surely Allah is Knowing, Wise."

(Surah al-Nisā', 4: 24)

There are various hadith of the Prophet Muhammad (BPUH) relating to the instructions of dower as well as the women rights on this issue. The relevant issue have been highlighted for emphasis:

Narrated 'Abd al-'Azīz bin Suhaib:

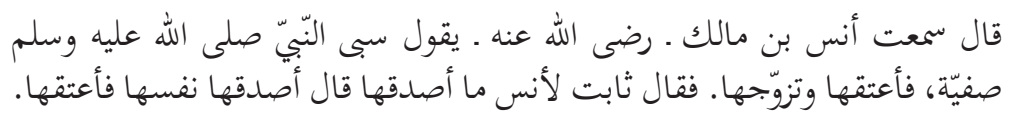

Anas bin Malik said, "The Prophet took Safiya as a captive. He manumitted her and married her." Thabit asked Anas, "What did he give her as mahr (i.e. marriage gift)?" Anas replied. "Her mahr was herself, for he manumitted her." 13

In addition, Anas retorted that the Messenger of Allah emancipated Safiyyah and married her also. He converts her emancipation as a form of dower. ${ }^{14}$

Prophet Muhammad (BPUH) advised that marriage as a form of contract that everyone can carry out and need to spend a suitable amount of money. It is also mentioned that the amount of the mahr which is a right of the woman which is to be given by the man is available in the Sunnah, "Even if you have an iron ring, give it to a woman as a dowry". ${ }^{15}$

Narrated Sahl bin Sad:

$$
\text { أنّ النّبّ صلى الله عليه وسلم قال لرجل تزوّج ولو بخاتم من حديد }
$$

The Prophet Muhammad (BPUH) said to a man, "Marry, even with (a mahr equal to) an iron ring." 16

\footnotetext{
13 Abū 'Abd Allāh Muḥammad Ibn Ismā'il al-Bukhārī, Șahīh al-Bukhārī, trans. Muḥammad Muḥsin Khan (Riyạ̣̄: Dār-al-Salām Ḥadīth, 1996), no. hadīth 513.

14 Abū 'Abd Allāh Muhammad Ibn Ismā'il al-Bukhārī, Șah̄ịh al-Bukhārī, no. hadīth 98.

15 Abū 'Abd Allāh Muḥammad Ibn Ismā'il al-Bukhārī, Ṣaḥịh al-Bukhārī, no. hadīth 80.

16 Abu'l-Hussain 'Asakir-ud-Din Muslim bin Hajjaj al-Qushayri al-Naisaburi, Sahih Muslim, translation by Abdul Hamid Siddiqui (New Delhi: Idara Impex, 2009), no. hadīth 76 .
} 
Hence, according to Islamic teaching or sunnah, mahr is the amount of some monetary value to be paid by the groom to the bride at the time of marriage. Some of which may be delayed according to what has been agreed upon between the spouses. ${ }^{17}$ Dower does not fix at any amount, but the husband must pay whatever amount that have been specified or whatever amount if not specified.

There are two types of dower which are prompt and deferred dower. Prompt dower becomes payable immediately after the marriage and must be paid at the time of wife's claim. If the prompt dower is not paid, the wife could refuse to stay with her husband under Muslim law. In this regards, the wife also can take legal action. In contrast, deferred dower becomes payable at the termination or dissolution of marriage either by death or divorce. In the case of unspecified dower, a husband is not released from his liability to pay a dower. Whereas the widow, therefore owns her husband's property under a claim for her dower. The other heirs of her husband are entitled to recover their respective shares upon for the dower debt proportionate to those shares. ${ }^{18}$

The provisions of dower could also be seen as respecting and recognizing the Muslim family laws. The relevant Muslim family laws are the Dissolution of Muslim Marriage Act 1939, the Muslim Family Laws Ordinance 1961, Muslim Marriage and Divorce (Registration) Act 1974, the Muslim Marriage and Divorce (Registration) Rules 1975 and the Family Court Ordinance 1985. Under the Muslim Family Laws Ordinance 1961, marriage was regarded as a civil contract. Section 5 of the Muslim Family Laws Ordinance makes it necessary that the marriage was solemnized under the Muslim Law and shall be registered. Where there were no details about the mode of payment for dower are specified in the Nikahnama, or the marriage contract. Here, it showed that the entire amount of the dower shall be presumed to be payable on demand. ${ }^{19}$

Dower in Muslim marriage forms an inseparable part for the terms of the Nikahnama and thus as the Nikahnama was intended to be registered under the Muslim Marriage and Divorce (Registration) Act 1974, so is the dower. It is a right for every woman acquires in a marriage under the marriage contract known as Nikahnama/Kabinama and according to the clauses 13-17, 20 of the Nikahnama prescribe the right to dower. The Act 1974 was in force and related to the registration of Muslim marriages including dower.

\footnotetext{
17 Syed Sahid Ahammad, 'A Critical Analysis of Dower (Mahr) in Islam,' Journal of Humanities and Social Science, vol. 21/7 (2016): 86.

18 David Pearl \& Werner Manski, Muslim Family Law, 180.

19 The Muslim Family Laws Ordinance 1961, section10.
} 
Subject to the provisions of the Muslim Family Laws Ordinance, 1961, a family court shall have exclusive jurisdiction to entertain, try and dispose of any case relating to dower. ${ }^{20}$ The period of limitation, according to section 113 of the Limitation Act 1908, for a case to recover prompt dower is three years from the date when the dower is demanded and refused; or where the marriage is dissolved by death or divorce. In case of deferred dower, the period of limitation is three years, from the date when the marriage is dissolved by death or divorce. However, prompt dower has not been fixed where a demand and refusal is not a condition precedent to filing a case for its recovery. ${ }^{21}$ If the dower is not paid by the husband to the wife and it was not paid even after her death, her heirs may demand dower payment.

The inherent idea behind dower is that it is an obligation imposed upon the husband as a sign of respect to the wife. ${ }^{22}$ It was held in Shafiqul Huq v. Mina Begum, ${ }^{23}$ that Family Court has got every jurisdiction to decide as to whether the Kabinnama in question as a genuine and valid document or not and whether any marriage between the petitioner and opposite party was ever solemnized or not before it decides to grant any decree for dower. It was further stated in the case of Jesmin Sultana v. Md. Elias ${ }^{24}$ that the court has no right to reduce the prompt dower unless the wife remits it voluntary. ${ }^{25}$

Therefore non-payment of dower fixed in Nikahnama will result in the breach of a registered contract. In Atiqul Huque Chowdhury v. Shahana Rahim ${ }^{26}$ it was decided that the dower in a Muslim marriage forms an unseparated part for the terms of the Kabinnama and thus, as the Kabinnama is intended to be registered under the Muslim Marriages and Divorces (Registration) Act, 1974. ${ }^{27}$ The Act of 1974 as in force, related to the registration of Muslim marriages including dower. ${ }^{28}$ In this regards, as per the Muslim Marriage and Divorce (Registration) Rules 1975, rule no. 24 (1) where the Nikahnama is silent about

20 The Family Courts Ordinance, 1985, section 5.

21 UNICEF, Marriage, Inheritance and Family Laws in Bangladesh: Towards A Common Family Code (Bangladesh: Collaborative Work of UNICEF and Women for Women - A Research and Study Group, 2005), 65.

22 Surah al-Nisa, verse 24, Surah al-Baqarah, verse 23 and verse 237.

23 Shafiqul Huq v. Mina Begum, Dhaka Law Report (DLR), 54, 481.

24 Jesmin Sultana v. Md. Elias, Bangladesh Legal Citation (BLC) 2, 233.

25 The Family Courts Ordinance, 1985, section 5.

26 Atiqul Huque Chowdhury v. Shahana Rahim, DLR 47, 1995 (HCD) 310.

27 The Muslim Marriage and Divorce (Registration) Rules 1975, rule no. 24 (1).

28 Taslima Monsoor, Gender Equity and Economic Empowerment: Family Law and Women in Bangladesh (Dhaka: British Council, 2008), 46. 
the division of prompt and deferred part of the dower, the whole amount will be presumed as prompt i.e. payable on demand. ${ }^{29}$

Furthermore, the Muslim Family Laws Ordinance 1961 stated that Arbitration Council instructed that the husband shall pay immediately the entire amount of the dower, whether prompt or deferred due to the existing wife or wives on which amount that was necessary. If the dower was not paid, it shall be recoverable as arrears of land revenue. ${ }^{30}$ In addition, it has been declared that it is an absolute right that a woman has in a marriage and according to the Dissolution of Muslim Marriage Act 1939 makes it clear, that nothing shall affect any right for a married woman under Muslim law for her dower. Whether the divorce was mentioned on any grounds under section 2 of Dissolution of Muslim Marriages Act 1939, the divorce cannot affect a woman's right for dower. ${ }^{31}$

\section{CHALLENGES OF THE APPLICATION OF DOWER'S RIGHT}

In Bangladesh, the non-payment of prompt dower is more common in society. The social reality shows that women rarely get any portion of their dower unless the husband is adamant to give divorce. In rural areas, 90\% of Muslim wives do not get any dower money at all whether prompt or deferred dower. The prompt dower is not paid for several reasons for example after marriage, most wives are reluctant to ask for it and they do not know all the conditions in the marriage deed which a document is written by their guardians. The husbands seldom pay the amount on their own. ${ }^{32}$

Sometimes the social position of female litigants who are economically dependent influences the claim for dower as the last financial support. In fact, it is difficult for the wife to recover the dower even after divorce. Although she has the power to go to the family court to demand her dower, but the family court procedure is lengthy and painful. Often she is not able to recover

29 Under the Nikahnama the dower may be prompt or deferred also it can be in forms of any valuable thing like property, ornaments or anything else which is agreed between the Muslim marriage partners. As per Muslim Marriage and Divorce (Registration) Rules 1975 rule no. 24 (1) where the Nikahnama is silent about the division of prompt and deferred part of the dower, the whole amount will be presumed as prompt i.e. payable on demand (sec 10 of the Muslim Family Law Ordinance 1961).

30 The Muslim Family Law Ordinance, Section 6(5) (a).

31 The Dissolution of Muslim Marriage Act 1939, section 2.

32 Taslima Monsoor, Gender Equity and Economic Empowerment: Family Law and Women in Bangladesh, 209. 
her prompt part of the dower as stated in the Kabinnama. Hence, dower, as practised, seems to have an unclear status as it is depending on the will of the husband. ${ }^{33}$ Consequently, a wife rarely gets any portion of her dower unless the husband is adamant to give divorce. Without intervention of the court, women can hardly get their dower. In this way, the cases of dower were shown as it was influenced by social practice and the question of payment arises only at the time of divorce. ${ }^{34}$

On the contrary, there is a social tradition and misconception on dower payment in the country where the husband begs to the wife for the relinquishment of her claim of dower in wedding night and wife accepts such request. According to Shariah and Muslim family law, a wife has no right to waive off her right to dower. This is again a misconception as there are law cases to suggest otherwise. It was held in Shah Banu Begum v. Iftekhar Md. $K_{h a n^{35}}$ that as she (the wife) did not act as a free agent, it would be iniquitous to say that a woman who remits dower in such circumstances is bound by it.

\section{DOWRY PRACTICE IN SOCIETY}

Dowry practise involves as a part of right for the bridal side in a Muslim marriage. The dowry refers to the money, goods, or estate from the bride's family given to the groom's family before the time of and during a marriage. It is not recognized in the Shariah or the law of the Muslim societies but it has spread widely. ${ }^{36}$ The concept of dowry originated from an ancient Hindu custom but now it has become a custom essential in all marriages. ${ }^{37}$ It is not only prevalent in a particular, illiterate marginal section of our society but unfortunately, the well-off educated section of the society contributes to the problem in the same way. It exists in various forms in the society and varies across the country depending upon economic conditions, societal structures, institutions, and family characteristics. ${ }^{38}$

33 UNICEF, Marriage, Inheritance and Family Laws in Bangladesh: Towards A Common Family Code, 65.

34 Taslima Monsoor, From Patriarchy to Gender Equity: Family Law and Its Impact on Women in Bangladesh, 199-205.

35 Shah Banu Begum v. Iftekhar Md. Khan, DLR 8 (WP) (1956) 133.

36 Taslima Monsoor, From Patriarchy to Gender Equity: Family Law and Its Impact on Women in Bangladesh, 222.

37 Nusrat Ameen, 'Dowry in Bangladesh: How Many More Deaths to Its End?' 128.

38 Taslima Monsoor, Management of Gender Relations: Violence against Women and Criminal Justice System in Bangladesh, 15. 
In Bangladeshi society, the dowry practice looked upon as a financial security, gift and seed capital for the new couple so that a husband can invest some amount of the dowry for a business or facilitate maintenance of their new family. The most common motives behind the dowry system are the grooms' and their families' greed, growing consumerism, excessive materialism, the need to evaluate status, and rising expectations to a better and luxurious life. Before 1981, dowry practice was not as popular as present day. During that time, the amount of dowry was very low but now the amount is very high and seen as more than double of dower money. Sometimes such payments usually go hand-in-hand with marriages arranged by the parents of the respective spouses. $^{39}$ There is a belief among males that the wife is a subject to her husband's marital power. According to this power, the husband is the head of the family and controls all financial matters in particular including dower payment and dowry demand. ${ }^{40}$ Besides, there are several socio-economic, cultural and religious factors which are responsible for such continuous persistence of dowry practice. ${ }^{41}$ In this way, dowry practice became as immoral cultures and comprises negative impact in the society.

\section{IMPACT OF DOWRY PRACTICE}

Although dowry is illegal, it is still socially accepted and seen as an abusive practice in Bangladesh. Many severe consequences are resulting from the payment of dowry and a common result of unpaid dowry is sending the wife back to her parent's house. Failure to meet dowry demands or the new demands often results in verbal and physical abuse ${ }^{42}$ of the wife.

In some cases, parents or guardians borrowed money for the dowry payment of their daughters. Often moderate poor households take loans from various NGOs and microfinance institutions to fulfil the dowry demand. Here it is

39 Siwan Anderson, 'The Economics of Dowry and Bride Price,' Journal of Economic Perspectives, vol. 21/4 (2007): 170.

40 H.R. Hahlo, 'Matrimonial Property Regimes: Yesterday, Today and Tomorrow', Osgoode Hall Law Journal, vol. 11/3 (1973): 458.

41 Fhameda Qudder, 'Dowry System in Bangladesh: A Socio-Legal Perspective', International Journal of Innovative Research and Development, vol. 3/7 (2014): 133.

42 Physical abuse includes beating; burning with cigarettes, withholding foods, sleep deprivation and denial of medical treatment. The abuse may be meted out by the husband or members of his family, especially his mother. Verbal abuse may include starting rumours about the character or behaviour of the wife and often the girls feel unable to disclose the situation to her parents. If the physical abuse continues and worsens, this may lead to the wife committing suicide. 
shown that they face many problems because of this dowry system. In this way, dowry pushes households into debts. Sometimes, husbands even control their wives' income as a source of wealth accumulation. ${ }^{43}$

Disputes over dowry payments have led to numerous cases of dowry violence against brides, resulting in injuries and even death. Many women filed divorce petitions to escape torture at the hands of in-laws for failing to meet the expectations of dowry. Every year many young women commit suicide or face physical torture after marriage because their parents cannot afford to give dowry. The woman has to live in a hostile environment where they become the victims of physical, social, mental and psychological torture. Women are driven to commit suicide because they were physically abused or even murdered over the claim of dowry and this has turned into a regular occurrence in society. It has reached the point where women are systematically abused by their husbands or in-laws over a long period of time or often to the length of their whole marriages that remains unreported. ${ }^{44}$

Recently, Ain O Salish Kendro ${ }^{45}$ reported that dowry related violence from January to September 2016 was 193 and from January to September 2017, it was reported that this violence was amounting to 221 cases. In reality, there are a huge number of untold and unreported incidents of torturing women both physically and psychologically. Women who were tortured and did not find a way to escape, choose the path of suicide. As a result, the existent trends of dowry are expedited, persisted and perpetuated. Women are being harassed, battered and tortured brutally for dowry. According to a statistics of Ain $O$ Salish Kendro, in 2018, there were 108 women were tortured physically and 126 women were tortured to death but only 95 cases were filed. ${ }^{46}$

Though there are statutory laws to uproot the vicious and this ruthless practice, the laws are still not enforced properly because dowry is still embedded in the heart of the society. This is mainly because of the lack of cooperation from the family members where women do not get the required support from the law. Some victims do not want to continue the legal battle against their

$43 \quad$ See Taskin Fahmina, 'Are you a silent observer of dowry and related violence?' odhikar.org, http://odhikar.org/are-you-a-silent-observer-of-dowry-and-relatedviolence/\#sthash.8TdjpCGH.dpuf, published on 22 August 2017, accessed on 12 June 2019.

44 Taslima Monsoor, Management of Gender Relations: Violence against Women and Criminal Justice System in Bangladesh, 37.

45 Ain O Salish Kendro (ASK) is a leading legal aid organization in Bangladesh.

46 Report of Ain O Salish Kendro, 2018. 
husbands for reprisal. As most victims come from poor families and losing the shelter of the husband's home can be a particularly frightening prospect. They cannot afford to fight in legal cases. In a judicial system where cases move forward at a slower rate, the woman and her family cannot continue to fund the legal procedures over many years to come. The result is to re-emphasize the systematic subordination of women that was at the root of the subject of dowry violence. ${ }^{47}$

\section{LEGAL PROTECTION}

The government of Bangladesh passed the Dowry Prohibition Act in $1980^{48}$ to ban dowry practice. This was the first anti-dowry criminal statutes in the country and subsequently modified in 1982, 1984 and 1986 for more effective outcome. In this regards, the Repression of Women and Children Act 2000 has been enacted for the protection of women. Here, it becomes pertinent to mention that the main focus of these Acts was the enhancement of punishment rather than prevention strategies. Instead, they have been implemented narrowly.

Dowry was legally banned by the Dowry Prohibition Act 1980. The Act has made dowry a criminal offence punishable with a maximum penalty of five years imprisonment and is fundamentally concerned with a series of issues including punishment for demanding, or taking and giving dowry, and also its investigation and trial proceedings. ${ }^{49}$ There is no noticeable change in the dowry practice since the enactment of the law. In some cases, the law is effective and in some cases, it is not. But the Act does not root-out the dowry practice as it was expected. In addition, the Act fails to recognize the gravity of the crime and the immorality involved in 'taking dowry' by placing dowry giver and dowry taker on an equal plane. It fails to take into account the unequal power balance in operation. Dowry-takers are more blameworthy as they are motivated by greed and utilize the groom's superior bargaining position.

The amendment of 1984 deleted section 6 of the Dowry Prohibition Act 1980 which had provided that any dowry given for the benefit of the wife or her heirs and received by any person was to be transferred by such person

47 Mohammad Abu Taher et al., 'Combating Dowry Violence against Women in Bangladesh: A Critical Study', International Journal of Innovation and Applied Studies, vol. 8/3 (2014): 1126.

48 The Dowry Prohibition Act 1980 (Act No. 35).

49 Afroza Begum, 'Revisiting Domestic Violence as A Gross Violation of Women's Fundamental Rights to Freedom From Torture', Rajshahi University Journal of Law, vol. 4 (2007): 19. 
to the women within a specified period of time..$^{50}$ The Dowry Prohibition Amendment Ordinance of 1986 did not fill the gap created by deletion section 6 of the Act. These amendments have also taken away an important right of the women to own property, thus depriving women economically. There are needs to mention that the Dowry Prohibition Act 1980 was repealed by the new Dowry Prevention Act 2018 which was enacted in 2018. A total of 11 sections have been included in the proposed Act. In the preamble of the Act of 2018, it is stated that the new Act has been enacted to meet the time's demand. ${ }^{51}$

The existing Act had no provision of imprisonment or fine for filing any false case on the dowry. The people who file a false case on claiming the dowry, the plaintiff will be guilty with the same charge where the minister noted. If a person abuses their wife now, they would be prosecuted under the Dowry Prohibition Act of 2018. The Act offers stricter punishment as it lays down 14 years' rigorous imprisonment along with fines for any individual(s) who incite any woman to commit suicide over dowry and it also has a provision for a lifeterm of 12 years for hurting a woman over dowry.

Another law is the Women and Children Repression Prevention Act 2000 (amended 2003). Under the section 11 (a) (b) and (c) of the Act also provisions for punishment of dowry violence, the highest punishment for killing a bride was death penalty. Section 11(a) of the said Act provides death sentence for causing murder, imprisonment for lifetime for attempting to murder, imprisonment from five to twelve years for grievous hurt and imprisonment from one to three years for simply hurting other person over the demand of dowry.

In the case of the State v. Azaharul Islam and others ${ }^{52}$ the court held that according to section 11(a) it is to be proved that death was caused because of demand for a dowry to push forward from the side of husband or father, mother, guardian or related to the husband or any person for and on behalf of the husband. In the State v. Oliar Rahman ${ }^{53}$ the High Court held that the trial court has rightly decided the sentence of death for death because of dowry for the wife. Such a person, who caused death of his wife, was seen as someone

50 Taslima Monsoor, 'Dowry Problem in Bangladesh: Legal and Socio-Cultural Perspective', Journal of Faculty of Law, The Dhaka University Studies, vol. 14/1 (2003): 11.

51 Nafiz Ahmed, 'Existing Laws Against Dowry Are Entirely Unhelpful', The Daily Star, 16 April 2019.

52 State v. Azaharul Islam and others, 3 LNJ (HDC) 2014, 862.

53 State v. Oliar Rahman, 4 Apex Law Report (ALR) (HCD) 2014, 16. 
who has no right to live in this world. He was seen as a person who committed cold-blooded murder of a village girl just because her parents and she have failed to meet his illegal demands. In such a situation, the High Court Division is of the view that the tribunal has committed no illegality in passing the sentence of death. ${ }^{54}$

Critics of the law point out that instead of protecting women as intended, these laws are widely used to harass people, including women of the husband's family. In many cases, in order to bring an offence of domestic violence that is not related to dowry demands within the law of 2000; false allegations of such demands are made. Unfortunately, these laws have not been beneficial to women in protecting her property rights. ${ }^{55}$

The Domestic Violence (Prevention and Protection) Act 2010 is another positive initiative by the government for addressing domestic violence against women. The beginning of The Act defines "domestic violence" in article 3 as "abuse in physical, psychological, economical and sexual nature against one person by any other person with whom that person is, or has been, in a family relationship, irrespective of the physical location where that Act takes place". The section is unique as it does not only defines a physical form of violence rather it includes psychological abuse but not limited to verbal abuse, harassment, and controlling behaviour. So in the case of physical or psychological abuse for dowry women can take resort to the Act.

Most of the time, filing a charge on dowry can be problematic for women since they have fear of expulsion from husband's residence, and also scared about her husband's unwillingness to continue matrimonial relation after she has taken legal action against him. Considering these facts, section 10 of the Act provides that the victim shall have every right to reside in the shared residence due to family relationship. The section 16 of the Act also does not provide any corrosive punishment rather it prescribes compensation. In practice, lack of effectiveness of relating laws and lack of professional ethics which concerned law agencies are not bringing expected results.

In Bangladesh, there are Special Courts established under the Women and Children Oppression Act to report the offences of dowry death and grievous. The 2000 Act provides for setting up of special courts where one court established in each district in Bangladesh. Additionally, Special Tribunals are

\footnotetext{
54 Md. Shahjahan (ed.), Yearly Law Digest, 2014 (Civil and Criminal) (Dhaka: Amin Book House, 2015), 328.

55 Mohammad Abu Taher et al., 'Combating Dowry Violence against Women in Bangladesh: A Critical Study’, 1130.
} 
set up under a special status called the Special Powers Act 1974. In 1983, there was another ordinance as mentioned before, to control oppression and violence against women called "Cruelty to Women (Deterrent Punishment) Ordinance". Under this Ordinance offences like kidnapping, trafficking, dowry death and torture, rape etc. are being discussed in special tribunal courts governed by the Special Powers Act 1974. These courts have the power to give death sentences, which should be confirmed by the High Court Division of the Supreme Court of Bangladesh. Unfortunately, because of several weaknesses in the criminal justice system, offenders get opportunities to take dowry, commit violence and go unpunished because of their crimes. This encourages potential offenders to commit the same crime in the future.

\section{CONCLUSION AND RECOMMENDATIONS}

Despite woman's participation in the socio-economic and political development, the woman still has less access to enjoy their dower rights rather they are humiliated because of dowry practice where subsequently they are living in violent marital life. In rural area, women are still not well educated. There is a social tradition that often husband attempts to reduce the amount of dower by different customary conventions. Moreover, most of the wife has no knowledge about her right for dower as she does not know any information about the legal mechanism for receiving it. Sometimes she takes an action after expiry of the time limitation for dower money and for that she never gets her dower money. This way women are being deprived and subordinated by the patriarchal family according to the wider socio-legal arena. In rural areas many marriages are taking place without Kabinnama, or with the kabinnama, it is not mentioned about what portion is prompt or what portion is deferred dower. For this reason, there is a tendency to give less amount as dower money and women's right to exercising the right of Talaq-e-Tafweed are curtailed.

Laws alone cannot purge the society from the dowry system as well as enforce dower practice. Besides laws, there is a need for more social awareness and effective social measures. For the protection of the women, the courts should be more sympathetic towards them and ensure their rights of dower. The right of dower should not be reduced or curtailed by any customary conventions or turning a case of Talaq to khula. It is not enough to make marriage registration mandatory rather monitoring forces should be constructed for ensuring registration of marriage. Moreover, an enquiry should be effectively done to examine the portion of dower money that has been really paid by the groom's part and what has been stated in the Kabinnama, both at 
the time of marriage and at the time of dissolution of marriage. Because there is a tendency to deprive the bride of her dower by deducting the fake price of jewellery on the part of the groom. So women should be more aware of her right for dower and it is the responsibility of the government, NGOs and civil society to disseminate the knowledge of dower among society.

Women and men have to be more conscious and aware about the right of dower under Shariah and statutory laws of Bangladesh and to ensure women right of the whole amount of dower money. The right of dower should not be reduced or curtailed by any customary tradition of dowry. Social awareness regarding women's right of dower should be ensured by inserting basis concepts of dower in the syllabus of primary or secondary education. Duties should be given to the Imams of mosques or to the Chairman of Union Parishad (local administration) to give awareness to the local people about women's right of dower. Similarly, liabilities for giving and taking dowry introduce unequal power balance in practice where mandatory arrest and proprosecution policies must be introduced to combat the dowry related violence. In dowry prosecution, the burden of proof should be shifted onto the accused in some respects such as proving that she/he did not commit dowry offence. Compulsory training should be introduced where focus must be given on the progress of law enforcement personnel for dowry violence against women rights and gender to remove negative and disrespectful attitude of police towards women. Legal aid services should be more accessible for the women so that they can bring their action within the proper time.

\section{REFERENCES}

Abū 'Abd Allāh Muhammad Ibn Ismā'il al-Bukhārī, Șaḥ̄ḥ al-Bukhārī, trans. Muhammad Muḥsin Khan (Riyāị: Dār-al-Salām Ḥadīth, 1996).

Afroza Begum, 'Revisiting Domestic Violence as A Gross Violation of Women's Fundamental Rights to Freedom From Torture', Rajshahi University Journal of Law, vol. 4 (2007): 19-25.

Ain o Salish Kendra (ASK), "Human Rights Situation in Bangladesh," http:// www.askbd.org/ask/2019/01/10/human-rights-situation-bangladesh2018-observation-ain-o-salish-kendra-ask/, accessed on 5 January 2019.

Aqil Ahmed, Mohammedan Law, 21 ${ }^{\text {st }}$ ed. (Allahabad: Central Law Agency, 2004).

David Pearl \& Werner Manski, Muslim Family Law (Lahore, Pakistan: Brite Books, 1998). 
Farah Deeba Chowdhury, 'Dowry, Women, and Law in Bangladesh', International Journal of Law, Policy and the Family, vol. 24/2 (2010): 198-221.

Fhameda Qudder, 'Dowry System in Bangladesh: A Socio-Legal Perspective', International Journal of Innovative Research and Development, vol. 3/7 (2014): 133-139.

H.R. Hahlo, 'Matrimonial Property Regimes: Yesterday, Today and Tomorrow', Osgoode Hall Law Journal, vol. 11/3 (1973): 455-478.

Md. Shahjahan (ed.), Yearly Law Digest, 2014 (Civil and Criminal) (Dhaka: Amin Book House, 2015).

Mohammad Abu Taher et al., 'Combating Dowry Violence against Women in Bangladesh: A Critical Study', International Journal of Innovation and Applied Studies, vol. 8/3 (2014): 1126-1131.

Nafiz Ahmed, 'Existing Laws Against Dowry Are Entirely Unhelpful', The Daily Star, 16 April 2019.

Nusrat Ameen, 'Dowry in Bangladesh: How Many More Deaths to Its End?' Journal of Faculty of Law, The Dhaka University Studies, vol. 8/1 (1997): 125-155.

Report of Human Rights Organization 'Odhikar', Annual Human Rights Report on Bangladesh, 2015. http://odhikar.org/annual-human-rightsreport-2015-odhikar-report-on-bangladesh/, accessed on 11 July 2019.

Siwan Anderson, 'The Economics of Dowry and Bride Price,' Journal of Economic Perspectives, vol. 21/4 (2007): 151-174.

Syed Sahid Ahammad, 'A Critical Analysis of Dower (Mahr) in Islam,' Journal of Humanities and Social Science, vol. 21/7 (2016): 86-91.

Taskin Fahmina, 'Are you a silent observer of dowry and related violence?' odhikar.org, http://odhikar.org/are-you-a-silent-observer-of-dowryand-related-violence/\#sthash.8TdjpCGH.dpuf, published on 22 August 2017, accessed on 12 June 2019.

Taslima Monsoor, 'Dowry Problem in Bangladesh: Legal and Socio-Cultural Perspective', Journal of Faculty of Law, The Dhaka University Studies, Part-F vol. 14/1 June (2003): 1-6.

Taslima Monsoor, From Patriarchy to Gender Equity: Family Law and Its Impact on Women in Bangladesh (Dhaka: The University Press Limited, 1999).

Taslima Monsoor, Gender Equity and Economic Empowerment: Family Law and Women in Bangladesh (Dhaka: British Council, 2008). 
Taslima Monsoor, Management of Gender Relations: Violence against Women and Criminal Justice System in Bangladesh (Dhaka: British Council, 2008).

UNICEF, Marriage, Inheritance and Family Laws in Bangladesh: Towards A Common Family Code (Bangladesh: Collaborative work of UNICEF and women for women- A Research and Study Group, 2005).

\section{Statutes}

3 LNJ (HDC) 2014, 862.

4 Apex Law Report (ALR) (HCD) 2014, 16.

Bangladesh Legal Citation (BLC) 2, 233.

Dhaka Law Report (DLR), 54, 481.

DLR 47, 1995 (HCD) 310.

DLR 8 (WP) (1956) 133.

The Dissolution of Muslim Marriage Act 1939.

The Dowry Prohibition Act 1980.

The Dowry Prohibition Act, 2018.

The Family Courts Ordinance, 1985.

The Muslim Family Laws Ordinance 1961.

The Muslim Marriage and Divorce (Registration) Rules 1975.

\section{Cases}

Atiqul Huque Chowdhury v. Shahana Rahim, DLR 47, 1995 (HCD) 310.

Jesmin Sultana v. Md. Elias, Bangladesh Legal Citation (BLC) 2, 233.

Shafiqul Huq v. Mina Begum, Dhaka Law Report (DLR), 54, 481.

Shah Banu Begum v. Iftekhar Md. Khan, DLR 8 (WP) (1956) 133.

State v. Azaharul Islam and others, 3 LNJ (HDC) 2014, 862.

State v. Oliar Rahman, 4 Apex Law Report (ALR) (HCD) 2014, 16. 